\title{
The Influence of Procurement Systems on Construction Projects in Rwanda
}

\author{
Musoni Nicolas, Gwaya Abednego, Wanyona Githae
}

\begin{abstract}
The Rwandan construction industry contributes up to $7.4 \%$ of the total GDP of 2010, yet its performance within the economy has been, and continues to be, very poor due to cost overruns resulting to abandonment of projects. The traditional design-bid-build system of procurement is still dominant in the Rwandan construction sector and this may likely continue to be the trend. Delay in project execution is a major problem in the Rwandan construction industry. This occurs both in small and large projects. Virtually, all the projects executed over the years in Rwanda were faced with problem of delay in delivery. The primary objective of the study is to analyze the influence of procurement systems on construction projects. Specific objectives are; to identify the extent to which various procurement systems commonly used by project managers in Kigali for construction projects, to examine influence of procurement systems encountered when employing various procurement systems for construction projects, to assess the merits and demerits of the various procurement systems on construction cost, develop a framework of procurement factors influencing delays. For the research design and methodology, the research will be carried out in Energy Development Corporation Limited as one of the institutions highly involved in the procurement and execution of construction works in Rwanda. The descriptive and explanatory approaches were done during the research and qualitative and quantitative methods were considered as well. About the sample size and target population, the researcher considers 21 as target population and census technique was used. Data analysis used spread sheets, SPSS and other statistic graphs and tables. The data collection instruments were questionnaires. The type of validity used by the researcher for this study was the content validity. For the reliability of the data collection instrument, Test- retest reliability was used. It is a measure of reliability obtained by administering the same test twice over a period of time to a group of individuals. The findings guided the researcher after analyzing data, to observe the influence of procurement systems on construction projects in Rwanda.
\end{abstract}

Keywords: Construction Project, Construction Industry, Performance, Procurement Systems.

Revised Manuscript Received on March 05, 2020.

* Correspondence Author

Mr. Musoni Nicolas, Student, Master's in construction project management, Jomo Kenyatta University of Agriculture and Technology (JKUAT).

Dr. Abednego Gwaya, Ph.D. (Constr. Eng. \& Mngt.); Jomo Kenyatta University of Agriculture and Technology (JKUAT)

Dr. Wanyona Githae, Senior lecturer, Jomo Kenyatta University of Agriculture and Technology (JKUAT)

(C) The Authors. Published by Blue Eyes Intelligence Engineering and Sciences Publication (BEIESP). This is an open access article under the CC BY-NC-ND license (http://creativecommons.org/licenses/by-nc-nd/4.0/)

\section{INTRODUCTION}

The construction industry is an important part of the economical backbone in many countries (Agarwal, et al, 2019) often accounting for between 7-10 percent of the Gross Domestic Product In Rwanda, this industry is of paramount importance for employment and economic growth (MINICOM, 2011, RDB, 2012). The GDP in the construction industry grew from RWF billion 105 in 2006 to RWF billion 244 in 2010. The sector contributed $6.1 \%, 6.5 \%, 7.5 \%, 7.3 \%$ and $7.4 \%$ of the total GDP in 2006, 2007, 2008, 2009 and 2010 respectively (NISR/BNR, 2010). Its performance within the economy has been and continue to be good. Construction is among industries which use high number of labor in Rwanda and views on prevailing business conditions and in the next decades are better for construction industry than other industries (MINICOM, 2011). The Rwandan construction industry continues to occupy an important position in the nation's economy even though it contributes less than the manufacturing. This industry plays an important role in the economy, and the products of its activities are so vital to the achievement of a national socio-economic development goals of creating job opportunities and social amenities and infrastructures (MINICOM, 2011).

There is insufficient information about the use of various types of procurement methods in Rwanda. For example there are questions wether the use of procurement can significantly affect the performance of most projects. Therefore, because of this gap, the researcher sought to undertake this study.

\section{STATEMENT IOF ITHE IPROBLEM}

The Rwanda construction industry is modeled after the French and Belgium systems, Belgium being our colonial master, although, in the post-tutsi genocide of 1994, it has incorporated the styles of United Kingdom and East African countries.

The traditional system of procurement is still dominant in Rwanda construction sector and this may likely continue to be the trend. In addition, the Rwandan construction sector comprises the clients, contractors, subcontractors, suppliers, and key professional actors responsible for design and supervision of projects (Aimable, SIBOMANA et al. 2015). 
The professional includes architects and engineers (structural and services). There are professional bodies that regulate the activities of these professionals.

Delay in project execution is a major problem in the Rwanda construction industry (Gitau, L. M. 2015, Mushuti, A. et al. 2016). This occurs in both small and large projects. Virtually, all the projects executed over the years in Rwanda were faced with the problem of delay in delivery. Musirikare and Kule (2016) observed that $65.7 \%$ of public construction projects which were implemented between 2009-2012 were delayed, whereas only $5.2 \%$ of these projects faced cost overruns.

Therefore, working with realistic procurement system is necessary at the outset of a project work, which would eliminate uncertainty and as well provide a platform for project success. Against this background the principal problem researched is:

"Several construction projects fail to meet the principal project objectives of budget, time and quality. This has been partially attributed to lack of knowledge of influence of procurement systems used for carrying out these projects, on each of the objectives and how best to select them"

This research therefore, undertakes to assess construction procurement systems frequencies of use and their impact on project objectives then determine influences of these procurement systems on project objectives and consequently project delivery.

\section{OBECTIVES OF THE STUDY}

○ To identify the extent to which various procurement systems are commonly used by project managers in Kigali for construction projects

- To establish the effect of procurement systems on construction cost

○ To identify the effect of procurement systems on construction time

○ To determine the effect of procurement systems on project management and quality

\section{Independent variables Dependent variables}

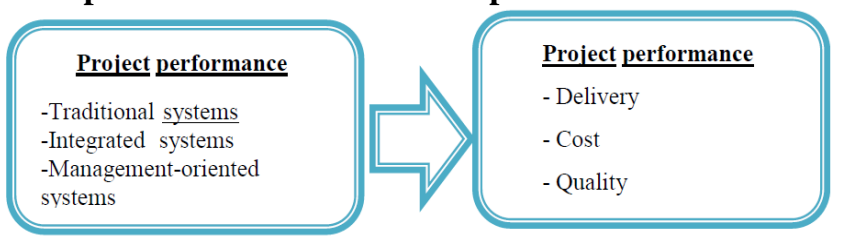

\section{RESEARCH METHODOLOGY}

This study adopted descriptive research design. It used survey research design. The target population of this study comprised of all EDCL staff involved in the procurement and the management of construction projects. Therefore the population comprised 8 procurement staff, 5 finance staff, 3 monitoring and evaluation staff and 3 project managers of EDCL. The total number of the population is hence 21 people. The researcher used census technique to incorporate the entire target population. To carry out this study a structured questionnaire was used to respondents. The researchdopted both qualitative and quantitative data analysis methods. Data analysis involved use of SPSS and the data provided by the questionnaire was analyzed using both descriptive and inferential statistical methods. Data was presented in tables. The following multivariate regression model was used in the study;

$\mathrm{Y}=\beta 0+\beta 1 \mathrm{X} 1+\beta 2 \mathrm{X} 2+\beta 3 \mathrm{X} 3+\varepsilon$

Where: $\mathrm{Y}=$ Project performance

$\beta 0$ = Constant Term;

$\beta 1, \beta 2, \beta 3$ and $\beta 4=$ Beta coefficients;

$\mathrm{X} 1=$ Traditional procurement systems

$\mathrm{X} 2=$ Integrated procurement systems

$\mathrm{X} 3=$ management-oriented procurement systems

$\varepsilon=$ Error Term

\section{RESEARCH FINDINGS AND DISCUSSSIONS}

\section{A. Level of education}

In the context of education qualification, $5 \%$ of the respondents had diploma qualification, $11 \%$ with undergraduate qualification and $84 \%$ of the respondents with post graduate qualification. The high number of respondents with postgraduate degree is explained by the increasing levels of persons with high education qualification in Rwanda.

Table 1: Level of education

\begin{tabular}{|l|l|l|}
\hline & Frequency & Percentage \\
\hline Diploma & 1 & 5 \\
& & \\
\hline Undergraduate & 2 & \\
\hline Post Graduate & 16 & 11 \\
\hline Total & $\mathbf{1 9}$ & 84 \\
\hline
\end{tabular}

\section{B.Professional qualification}

To be sure if all groups of staff involved in the procurement and management of construction projects were represented, frequencies of groups of staff were calculated. In this context procurement staff represent $36.8 \%$ of respondents, project managers represent $21.1 \%$, financial staff represent $26.3 \%$ while monitoring and evaluation staff represent $15.8 \%$.

Table 2: Professional qualification

\begin{tabular}{|l|l|l|}
\hline & Frequency & Percentage \\
\hline $\begin{array}{c}\text { Procurement } \\
\text { staff }\end{array}$ & 7 & 36.8 \\
\hline $\begin{array}{c}\text { Project } \\
\text { managers }\end{array}$ & 4 & 21.1 \\
\hline Financial staff & 5 & 26.3 \\
\hline $\begin{array}{c}\text { Monitoring and } \\
\text { evaluation staff }\end{array}$ & 3 & 15.8 \\
\hline Total & $\mathbf{1 9}$ & $\mathbf{1 0 0}$ \\
\hline
\end{tabular}




\section{C.Working iexperience}

The working experience is important in indicating the knowledge level of the respondents in relations to procurement and management of construction projects. A majority of the respondents (52.6\%) had worked for between 6-10 years compared to $1-5$ years (15.8\%), 11-15 years (21.1\%), 16-20 years (10.5\%). No respondent has worked over 20 years.

Table 3: Working experience

\begin{tabular}{|l|l|l|}
\hline & Frequency & Percentage \\
\hline 1 -5 years & 3 & 15.8 \\
\hline 6-10 years & 10 & \\
\hline 11-15 years & 4 & 52.6 \\
\hline 16-20 years & 2 & 21.1 \\
\hline $\begin{array}{c}\text { Over 20 } \\
\text { years }\end{array}$ & 0 & 10.5 \\
\hline Total & $\mathbf{1 9}$ & 0 \\
\hline
\end{tabular}

D.Descriptive statistics on identification of various procurement systems commonly used by project managers in Kigali for construction projects

The metrics traditional systems, Two-stage selective tendering and Negotiation had means between 3.5 and 4.5 indicating that on average the procurement systems are used. Concerning Continuity Contracts, Serial Contracts and Cost-reimbursement system, the means are 2.36, 2.36 and 3.15 respectively. This implies that on average these procurement systems are not used in Rwanda.

Apart Cost-reimbursement system, all other procurement systems metrics had standard deviations between 0.5 and 1 meaning moderate consensus amongst the respondents in relations to the use of various procurement systems. Cost-reimbursement system had a standard deviation of 1.21 which implied that the data was widely dispersed from the mean. This implied a lack of consensus on the given metric.
For group 2, the use of Design and build had a mean of 4.42 and a standard deviation of 0.83 . The use of Package deals had a mean of 2.00 and a standard deviation of 1.15. The use of Turnkey had a mean and a standard deviation of 3.57 and 0.89 respectively. The use of EPC had a mean and a standard deviation of 4.31 and 0.88 respectively. Finally in this group, the use of Develop and construct system had a mean and a standard deviation of 2.52 and 0.93 respectively.

The metrics Design and build, Turnkey and EPC had means between 3.5 and 4.5 indicating that on average the procurement systems are used. Concerning Package deals and Develop and construct, the means are $2.00,2.52$ respectively. This implies that on average these procurement systems are not used in Rwanda.

According standard deviations, unless Package deals, other procurement systems metrics had standard deviations between 0.5 and 1 meaning moderate consensus amongst the respondents in relations to the use of various procurement systems. For Package deals the standard deviation is 1.15 which implied that the data was widely dispersed from the mean. This implied a lack of consensus on the given metric.

Finally for group 3, the use of Management contracting had a mean of 2.00 and a standard deviation of 0.99 . The use of Construction management had a mean of 4.05 and a standard deviation of 0.94 .

The metric Construction management had mean between 3.5 and 4.5 indicating that on average the procurement system is used. Concerning Construction management, the mean is 2.00. This implies that on average this procurement systems is not used in Rwanda.

According standard deviations, the procurement systems metrics had standard deviations between 0.5 and 1 meaning moderate consensus amongst the respondents in relations to the use of various procurement systems.

Table 4: Frequency distribution of various procurement systems commonly used in Kigali for construction projects

\begin{tabular}{|l|l|l|l|l|l|l|c|}
\hline & 1 & 2 & 3 & 4 & 5 & Mean & $\begin{array}{l}\text { Std. } \\
\text { Deviation }\end{array}$ \\
\hline Separated and Cooperative & & & & & & & \\
\hline Traditional & $\begin{array}{l}9 \\
(47.4 \%)\end{array}$ & $\begin{array}{l}6 \\
(31.6 \%)\end{array}$ & $\begin{array}{l}3 \\
(15.8 \%)\end{array}$ & $\begin{array}{l}1 \\
(5.3 \%)\end{array}$ & & 4.21 & 0.91 \\
\hline Two-stage selective tendering & $\begin{array}{l}7 \\
(42.1 \%)\end{array}$ & $\begin{array}{l}(36.8 \%) \\
10.5 \%)\end{array}$ & $\begin{array}{l}1 \\
(5.3 \%)\end{array}$ & $\begin{array}{l}1 \\
(5.3 \%)\end{array}$ & 4.05 & 0.96 \\
& $\begin{array}{l}4 \\
\text { Negotiation }\end{array}$ & $\begin{array}{l}3 \\
(21.1 \%)\end{array}$ & $\begin{array}{l}3 \\
(15.8 \%)\end{array}$ & $\begin{array}{l}1 \\
(5.3 \%)\end{array}$ & $\begin{array}{l}1 \\
(5.3 \%)\end{array}$ & 4.10 & 0.95 \\
\hline Continuity Contracts & & $\begin{array}{l}7 \\
(10.5 \%)\end{array}$ & $\begin{array}{l}6 \\
(36.8 \%)\end{array}$ & $\begin{array}{l}4 \\
(21.6 \%)\end{array}$ & 2.36 & 0.95 \\
\hline
\end{tabular}


The Influence of Procurement Systems on Construction Projects in Rwanda

\begin{tabular}{|c|c|c|c|c|c|c|c|}
\hline Serial Contracts & & $\begin{array}{l}1 \\
(5.3 \%)\end{array}$ & $\begin{array}{l}9 \\
(47.4 \%)\end{array}$ & $\begin{array}{l}5 \\
(26.3 \%)\end{array}$ & $\begin{array}{l}4 \\
(21.1 \%)\end{array}$ & 2.36 & 0.89 \\
\hline Cost Reimbursement & $\begin{array}{l}2 \\
(10.5 \% \\
\end{array}$ & $\begin{array}{l}7 \\
(36.8 \%) \\
\end{array}$ & $\begin{array}{l}4 \\
(21.1 \%)\end{array}$ & $\begin{array}{l}4 \\
(21.1 \%)\end{array}$ & $\begin{array}{l}2 \\
(10.5 \%)\end{array}$ & 3.15 & 1.21 \\
\hline & 1 & 2 & 3 & 4 & 5 & Mean & $\begin{array}{c}\text { Std. } \\
\text { Deviation }\end{array}$ \\
\hline \multicolumn{8}{|l|}{ Integrated } \\
\hline Design and build & $\begin{array}{l}11 \\
(57.9 \%) \\
\end{array}$ & $\begin{array}{l}6 \\
31.6 \%) \\
\end{array}$ & $\begin{array}{l}1 \\
(5.3 \%) \\
\end{array}$ & $\begin{array}{l}1 \\
(5.3 \%) \\
\end{array}$ & & 4.42 & 0.83 \\
\hline Package deals & $\begin{array}{l}1 \\
(5.3 \%) \\
\end{array}$ & $\begin{array}{l}1 \\
(5.3 \%) \\
\end{array}$ & $\begin{array}{l}3 \\
(15.8 \%) \\
\end{array}$ & $\begin{array}{l}6 \\
(31.6 \%) \\
\end{array}$ & $\begin{array}{l}8 \\
(42.1 \%) \\
\end{array}$ & 2.00 & 1.15 \\
\hline Turnkey & $\begin{array}{l}5 \\
(26.3 \%) \\
\end{array}$ & $\begin{array}{l}6 \\
(31.6 \%) \\
\end{array}$ & $\begin{array}{l}4 \\
(21.1 \%)\end{array}$ & $\begin{array}{l}3 \\
(15.8 \%) \\
\end{array}$ & $\begin{array}{l}1 \\
(5.3 \%) \\
\end{array}$ & 3.57 & 0.89 \\
\hline EPC & $\begin{array}{l}10 \\
(52.6 \%) \\
\end{array}$ & $\begin{array}{l}6 \\
(31.6 \%) \\
\end{array}$ & $\begin{array}{l}2 \\
(10.5 \%)\end{array}$ & $\begin{array}{l}1 \\
(5.3 \%) \\
\end{array}$ & & 4.31 & 0.88 \\
\hline Develop and construct & $\begin{array}{l}1 \\
(5.3 \%) \\
\end{array}$ & $\begin{array}{l}2 \\
(10.5 \%) \\
\end{array}$ & $\begin{array}{l}7 \\
(36.8 \%) \\
\end{array}$ & $\begin{array}{l}5 \\
(26.3 \%) \\
\end{array}$ & $\begin{array}{l}4 \\
(21.1 \%) \\
\end{array}$ & 2.52 & 0.93 \\
\hline & 1 & 2 & 3 & 4 & 5 & Mean & $\begin{array}{l}\text { Std. } \\
\text { Deviation }\end{array}$ \\
\hline \multicolumn{8}{|l|}{ Management-oriented } \\
\hline Management contracting & & $\begin{array}{l}1 \\
(5.3 \%)\end{array}$ & $\begin{array}{l}7 \\
(38.8 \%)\end{array}$ & $\begin{array}{l}2 \\
(10.5 \%)\end{array}$ & $\begin{array}{l}9 \\
(47.4 \%)\end{array}$ & 2.00 & 0.99 \\
\hline Construction management & $\begin{array}{l}9 \\
(47.4 \%)\end{array}$ & $\begin{array}{l}5 \\
(26.3 \%)\end{array}$ & $\begin{array}{l}3 \\
(15.8 \%)\end{array}$ & $\begin{array}{l}1 \\
(5.3 \%)\end{array}$ & $\begin{array}{l}1 \\
(5.3 \%)\end{array}$ & 4.05 & 0.94 \\
\hline
\end{tabular}

E. Descriptive statistics on Impact of procurement systems on construction cost

The impact of procurement systems on construction cost was examined using three metrics groups following the 3 main groups of procurement systems. To each group are associated 3 metrics which are impacts. Hence the total metrics are 9. In this context, Traditional systems tend to decrease the final project cost had a mean of 4.05 and a standard deviation of 0.77 . The final project cost will be lower than when using other procurement methods had a mean of 3.78 and a standard deviation of 0.84. Finally, traditional systems tend to increase the final project cost had a mean and a standard deviation of 1.78 and 0.71 respectively.

The metrics , Traditional systems tend to decrease the final project cost and The final project cost will be lower than when using other procurement methods had means between 3.5 and 4.5 indicating that on average they are Impacts of traditional procurement systems on construction cost in Rwanda. For Traditional systems tend to increase the final project cost, the mean is 1.78. This implies that this metric is not an Impact of traditional procurement systems on construction cost in Rwanda.

Impacts of traditional procurement systems on construction cost as metrics had standard deviations between 0.5 and 1 meaning moderate consensus amongst the respondents in relations to the use of various procurement systems.

For group 2, Integrated systems tend to decrease the final project cost had a mean of 3.42 and a standard

Table 5. Frequency distribution of impact of procurement systems on construction cost

\begin{tabular}{|l|l|l|l|l|l|l|l|}
\hline & 1 & 2 & 3 & 4 & 5 & Std. \\
Deviation
\end{tabular}




\begin{tabular}{|l|l|l|l|l|l|l|l|}
\hline $\begin{array}{l}\text { The final project cost will } \\
\text { be lower than when using } \\
\text { other procurement methods }\end{array}$ & $(26.3 \%)$ & $\begin{array}{l}8 \\
(42.1 \%)\end{array}$ & $\begin{array}{l}4 \\
(21.1 \%)\end{array}$ & $\begin{array}{l}1 \\
(5.3 \%)\end{array}$ & $\begin{array}{l}1 \\
(5.3 \%)\end{array}$ & 3.78 & 0.84 \\
\hline $\begin{array}{l}\text { Traditional systems tend to } \\
\text { increase the final project } \\
\text { cost }\end{array}$ & $\begin{array}{l}3 \\
(15.8 \%)\end{array}$ & $\begin{array}{l}9 \\
(47.7 \%)\end{array}$ & $\begin{array}{l}7 \\
(36.8)\end{array}$ & & & 1.78 & 0.71 \\
\hline
\end{tabular}

\begin{tabular}{|l|l|l|l|l|l|l|l|}
\hline & 1 & 2 & 3 & 4 & 5 & Mean & $\begin{array}{l}\text { Std. } \\
\text { Deviation }\end{array}$ \\
\hline $\begin{array}{l}\text { Integrated systems tend to } \\
\text { decrease the final project } \\
\text { cost }\end{array}$ & $\begin{array}{l}3 \\
(15.8 \%)\end{array}$ & $\begin{array}{l}5 \\
(26.3 \%)\end{array}$ & $\begin{array}{l}8 \\
(42.1 \%)\end{array}$ & $\begin{array}{l}3 \\
(15.8 \%)\end{array}$ & & 3.42 & 0.95 \\
\hline $\begin{array}{l}\text { Integrated systems tend to } \\
\text { increase the final project } \\
\text { cost }\end{array}$ & $(26.3 \%)$ & $\begin{array}{l}8 \\
(42.1 \%)\end{array}$ & $\begin{array}{l}4 \\
(21.1 \%)\end{array}$ & $\begin{array}{l}1 \\
(5.3 \%)\end{array}$ & $\begin{array}{l}1 \\
(5.3 \%)\end{array}$ & 3.78 & 0.95 \\
\hline $\begin{array}{l}\text { The final project cost will } \\
\text { be lower than when using } \\
\text { other procurement methods }\end{array}$ & & $\begin{array}{l}3 \\
(15.8 \%)\end{array}$ & $\begin{array}{l}8 \\
(42.1 \%)\end{array}$ & $\begin{array}{l}8 \\
(42.1 \%)\end{array}$ & 1.73 & 0.71 \\
\hline
\end{tabular}

\begin{tabular}{|l|l|l|l|l|l|l|l|}
\hline & 1 & 2 & 3 & 4 & 5 & Mean & $\begin{array}{l}\text { Std. } \\
\text { Deviation }\end{array}$ \\
\hline $\begin{array}{l}\text { Management-oriented } \\
\text { systems tend to decrease } \\
\text { the final project cost }\end{array}$ & 9 \\
$(47.4 \%)$ & $\begin{array}{l}7 \\
(36.8 \%)\end{array}$ & $\begin{array}{l}2 \\
(10.5 \%)\end{array}$ & $\begin{array}{l}1 \\
(5.3 \%)\end{array}$ & & 4.26 & 0.87 \\
\hline $\begin{array}{l}\text { Management-oriented } \\
\text { systems tend to increase } \\
\text { the final project cost }\end{array}$ & $\begin{array}{l}1 \\
(5.3 \%)\end{array}$ & $\begin{array}{l}3 \\
(15.8 \%)\end{array}$ & $\begin{array}{l}6 \\
(31.6 \%)\end{array}$ & $\begin{array}{l}9 \\
(47.4 \%)\end{array}$ & 1.78 & 0.71 \\
\hline $\begin{array}{l}\text { The final project cost will } \\
\text { be higher than when using } \\
\text { other procurement methods }\end{array}$ & $\begin{array}{l}1 \\
(5.3 \%)\end{array}$ & $\begin{array}{l}7 \\
(36.8 \%)\end{array}$ & $\begin{array}{l}8 \\
(42.1 \%)\end{array}$ & $\begin{array}{l}3 \\
(15.8 \%)\end{array}$ & 2.31 & 0.82 \\
\hline
\end{tabular}

deviation of 0.95. Integrated systems tend to increase the final project cost had a mean of 3.78 and a standard deviation of 0.95 . Finally, The final project cost will be lower than when using other procurement methods had a mean and a standard deviation of 1.73 and 0.71 respectively.

Only Integrated systems tend to increase the final project cost had mean between 3.5 and 4.5 indicating that on average it is an Impact of Integrated system on construction cost in Rwanda.

Impacts of integrated procurement systems on construction cost as metrics had standard deviations between 0.5 and 1 meaning moderate consensus amongst the respondents in relations to the use of various procurement systems.

Concerning group 3, Management-oriented systems tend to decrease the final project cost had a mean of 4.26 and a standard deviation of 0.87 . Management-oriented systems tend to increase the final project cost had a mean of 1.78 and a standard deviation of 0.71 . Finally, The final project cost will be higher than when using other procurement methods had a mean and a standard deviation of 2.31 and 0.82 respectively.

Only Management-oriented systems tend to decrease the final project cost had mean between 3.5 and 4.5 indicating that on average it is an Impact of Integrated system on construction cost in Rwanda.

Impacts of Management-oriented procurement systems on construction cost as metrics had standard deviations between 0.5 and 1 meaning moderate consensus amongst the respondents in relations to the use of various procurement systems.

\section{F. Descriptive statistics on Impact of procurement} systems on construction time

Similarly, with the precedent subsection, the impact of procurement systems on construction time was examined using three metrics groups following the 3 main groups of procurement systems. To each group are associated 3 metrics which are impacts.

Hence the total metrics are 9. In this context, in group 1, Traditional systems decrease the construction time had a mean of 2.10 and a standard deviation of 0.76. Traditional systems increase the construction time had a mean of 3.78 and a standard deviation of 0.74 . Finally, Traditional systems are the slowest project delivery approach had a mean and a standard deviation of 4.05 and 0.77 respectively. 
Traditional systems increase the construction time and Traditional systems are the slowest project delivery approach had means between 3.5 and 4.5 indicating that on average they are Impacts of traditional procurement systems on construction time in Rwanda. For Traditional systems decrease the construction time, the mean is 1.78. This implies that this metric is not an Impact of traditional procurement systems on construction time in Rwanda.

Impacts of traditional procurement systems on construction time as metrics had standard deviations between 0.5 and 1 meaning moderate consensus amongst the respondents in relations to the use of various procurement systems.

For group 2, Integrated systems decrease the construction time had a mean of 3.84 and a standard deviation of 0.82 . Integrated systems increase the construction time had a mean of 2.84 and a standard deviation of 0.83 . Finally, Integrated systems are the fastest project delivery approach had a mean and a standard deviation of 1.8 and 0.87 respectively.

Only Integrated systems decrease the construction time had mean between 3.5 and 4.5 indicating that on average it is an Impact of Integrated system on construction time in Rwanda.

Impacts of integrated procurement systems on construction time as metrics had standard deviations between 0.5 and 1 meaning moderate consensus amongst the respondents in relations to the use of various procurement systems.

Concerning group 3, Management-oriented systems decrease the construction time had a mean of 3.94 and a standard deviation of 0.84. Management-oriented systems increase the construction time had a mean of 3.47 and a standard deviation of 0.84. Finally, Management-oriented systems are the fastest project delivery approach had a mean and a standard deviation of 4.21 and 0.88 respectively.

Management-oriented systems decrease the construction time and Management-oriented systems are the fastest project delivery approach had mean between 3.5 and 4.5 indicating that on average they are Impacts of Integrated system on construction time in Rwanda.

Impacts of Management-oriented procurement systems on construction cost as metrics had standard deviations between 0.5 and 1 meaning moderate consensus amongst the respondents in relations to the use of various procurement systems.

\section{G. Descriptive statistics on Impact of procurement systems on construction quality}

The impact of procurement systems on construction project management and quality was examined using one metric: Procurement systems affect construction quality. Procurement systems affect construction quality had a mean of 4.10 and a standard deviation of 087 . Procurement systems affect construction quality had mean between 3.5 and 4.5 indicating that on

average it is an Impact of Procurement systems on construction project management and quality in Rwanda.

The impact of procurement systems on construction project management and quality as metric had standard deviations between 0.5 and 1 meaning moderate consensus amongst the respondents in relations to the use of various procurement systems.

\section{H. Correlation analysis}

Correlation analysis was carried out to examine linear correlation between independent variables and dependent variables.

A Pearson correlation is a number between -1 and 1 that indicates the extent to which two variables are linearly related.

All Pearson correlation coefficients between each independent variable and dependent variable are above 0.5 , which means that the relationship is statistically significant.

\section{Regression analysis}

To examine the influence of the independent variables on the dependent variables, the regression analysis was undertaken yielding the below regression model;

$\mathrm{Y}=1.189-0.093 \mathrm{X} 1-0.028 \mathrm{X} 2+0.853 \mathrm{X} 3+0.68373$

Where $\mathrm{X} 1=$ traditional procurement systems

$\mathrm{X} 2=$ integrated procurement systems

$\mathrm{X} 3=$ management-oriented procurement systems

\section{CONCLUSION}

From the results of the study a number of conclusions are made. Firstly various procurement systems used for construction projects were determined.

Secondly the research has also shown that there is relationship between these various procurement systems and cost and time of construction projects.

All the key areas stating the impact of these various procurement systems on the cost and time were identified. Finally the research shown the use of various procurement systems can affect the quality of a construction.

This research thus has established the need for appropriate suggestions and recommendations on the adequate choice of the procurement system to use for a construction project for an optimum performance.

\section{REFERENCES}

1. AbdulAzeez, A. D. U., Badiru, Y. Y., \& Gabriel, B. B. (2015). A survey of public construction management agencies readiness for E-procurement adoption. Jurnal Teknologi, 77(15).

2. Acheamfour, V. K., Kissi, E., \& Adjei-Kumi, T. (2019). Ascertaining the impact of contractors pre-qualification criteria on project success criteria. Engineering, Construction and Architectural Management.

3. Agyapong, A. (2016). Viability of management procurement system in the construction industry of Ghana (Doctoral dissertation).

4. Aires, M., Gamez, R., \& Gibb, A. G. (2016). The impact of occupational health and safety regulations on prevention through design in construction projects: perspectives from Spain and the United Kingdom.

5. Al-Tmeemy, S. M. H., \& Amer Hatem, W. (2015). The consequences of poor quality on project management success of building projects. Diyala journal of engineering sciences, 8(4), 172-182. 
6. Amandin, M. M., \& Kule, J. W. (2016). Project delays on cost overrun risks: a study of Gasabo district construction projects Kigali, Rwanda. ABC Journal of Advanced Research, 5(1), 21-34.

7. Amoatey, C. T., Ameyaw, Y. A., Adaku, E., \& Famiyeh, S (2015). Analysing delay causes and effects in Ghanaian state housing construction projects. International Journal of Managing Projects in Business, 8(1), 198-214.

8. Arashpour, M., Wakefield, R., Blismas, N., \& Minas, J. (2015) Optimization of process integration and multi-skilled resource utilization in off-site construction. Automation in Construction, 50, 72-80.

9. Ashworth, A., \& Perera, S. (2018). Contractual procedures in the construction industry. Routledge.

10. Avgerou, C., \& Walsham, G. (Eds.). (2017). Information technology in context: Studies from the perspective of developing countries: Studies from the perspective of developing countries. Routledge.

11. Badiru, A. B., \& Osisanya, S. O. (2016). Project management for the oil and gas industry: a world system approach. CRC Press.

12. Beach, R., \& Tierney, R. J. (2016). Toward a theory of literacy meaning making within virtual worlds. Handbook of research on reading comprehension, 2, 135-164.

13. Belay, M. D., Tekeste, E. A., \& Ambo, S. A. (2017) Investigation of Major Success Factors on Building Construction Projects Management System in Addis Ababa, Ethiopia. American, of Civil Engineering, 5(3), 155-163.

\section{AUTHOR PROFILE}

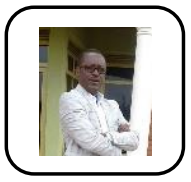

Mr. Musoni Nicolas Student, Master's in construction project management, Jomo Kenyatta University of Agriculture and Technology (JKUAT), Consultant in construction and civil engineering, Kigali, Rwanda, registered engineer.

University of Rwanda.

He studied Bachelor of Science in Civil engineering at the

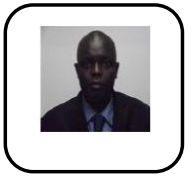

Dr. Abednego Gwaya

A. Academic Professional Qualification

B.A (Bldg. Econ.) Hons; University of Nairobi, MSc. (Civil Eng.); Makerere, Ph.D. (Constr. Eng. \& Mngt.); Jomo Kenyatta University of Agriculture and Technology (JKUAT) M.A.A.K. (Q.S); C.I.Q.S.K; Registered Q.S.

He specializes in Construction Project Management, Civil Engineering Construction, Contract Documentation, Project Management Modelling, Project Procurement Systems and General Quantity Surveying.

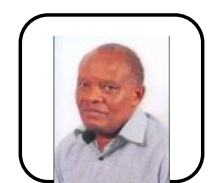

Dr. Wanyona Githae, B.A (Bldg. Econ.) Hons; University of Nairobi, (PhD, University of Cape Town) Building Economics, Risk Management), Senior lecturer, Jomo Kenyatta University of Agriculture and Technology (JKUAT) M.A.A.K. (Q.S); C.I.Q.S.K; Registered Q.S. 